\title{
Isolation and Characterization of Hederagenin from Hedera helix L. Extract with Antitumor Activity
}

\begin{abstract}
RODICA TATIA ${ }^{1}$, CHRISTINA ZALARU2*, ISABELA TARCO MNICU ${ }^{3}$, LUCIA MOLDOVAN ${ }^{1}$, OANA CRACIUNESCU ${ }^{1}$, IOAN CALINESCU ${ }^{4}$ ${ }^{1}$ National Institute of Research and Development for Biological Sciences, Department of Cellular and Molecular Biology, 296 Splaiul Independentei, 060031, Bucharest, Romania

ZUniversity of Bucharest, Faculty of Chemistry, Department of Organic Chemistry, Biochemistry and Catalysis, 90-92 Panduri Str., 050663, Bucharest, Romania

${ }^{3}$ Cytogenomic Medical Laboratory, 35 Floreasca Str., 014462, Bucharest, Romania

${ }^{4}$ University Politehnica of Bucharest, Faculty of Applied Chemistry and Materials Science, Department of Bioresources and Polymer Science, 1-7 Gh. Polizu Str., 011061, Bucharest, Romania

Hederagenin, a saponin known for its therapeutic effect was isolated from leaves of Hedera helix. Hederagenin was obtained by repeated maceration of ground plant material in $95 \%(\mathrm{v} / \mathrm{v})$ ethanol. The ethanolic extract was subjected to acid hydrolysis and purification with acetonitrile. Isolated hederagenin (IHe) was analyzed by HPLC-MS/MS and compared to standard hederagenin. In vitro cytotoxicity of IHe was tested in a culture of fibroblast cells from NCTC clone L929 cell line by MTT assay, using dioscin as positive control. For the determination of IHe antitumor effect, in vitro tests were performed in a culture of human cervix carcinoma Hep-2 cells cultivated in the presence of different concentrations of sample for $48 \mathrm{~h}$. IHe was biocompatible in the range of concentrations 2-200 $\mu \mathrm{g} / \mathrm{mL}$, in NCTC cell culture. The compound showed cell cytotoxicity in the concentration range of $100-400 \mu \mathrm{g} / \mathrm{mL}$, in Hep-2 cell culture, revealing its antitumor activity. These results demonstrated the possible use of hederagenin isolated from $\mathrm{H}$. helix extract as an antitumor agent.
\end{abstract}

Keywords: Hedera helix L., hederagenin, HPLC-MS/MS, in vitro cytotoxicity, antitumor effect

Plant-derived compounds have played an important role in the provision of new structural leaders for the discovery of many useful therapeutic agents [1]. Hedera helix L. or ivy is a perennial and evergreen plant known for its biological activity [2]. In traditional medicine, infusions obtained from young ivy leaves are used in relieving cough and bronchial spasms, due to their expectorant action. Ivy infusions also exert analgesic, sedative, antiparasitic, cytotoxic and emmenagogue actions [3]. The external application of ivy leaves decoction showed antifungal, antibacterial and anti-cellulite activities [4]. All these properties required scientific research to justify this plant use for medicinal purposes. The active ingredients found in $H$. helix extracts were saponins, polyphenolic acids, including caffeic and chlorogenic acids, flavonol glycosides, such as rutin and rhamnoglucosyl-3campherol, sterols, such as sitosterol and stigmasterol, sesquiterpenes and polyacetylenes, such as falcarinone and falcarinol, anthocyanins, coumarins, amino acids, vitamins, volatile and liquid oils and $\beta$-lecithin $[5,6]$.

The main therapeutic effects of ivy extract are due to its composition rich in triterpene saponins (2.5-6\%) of bidesmosidic glycosides type, like hederacoside $C$ (1.7$4.8 \%)$, hederacoside D $(0.4-0.8 \%)$, hederacoside B $(0.1$ $0.2 \%$ ) and monodesmosidic glycerides of the oleanolic acid, such as $\alpha$-hederin (0.1-0.3\%), ä-hederin and hederagenin [2, 7-9]. Hederagenin, the aglycone part of saponins is a pentacyclic triterpene possessing two hydroxyl groups in ring $A$, a double bond in ring $C$ and a carboxylic group at C-28 position (fig. 1) [4]. It shows some interesting biological properties, such as anti-inflammatory [10], antifungal [11, 12], antimicrobial [13, 14] and anticancer activity $[2,15]$. In vitro studies on HeLa colon carcinoma cells and in vivo studies revealed that hederagenin had a significant antitumor effect $[15,16]$.

\footnotetext{
* email: chmzalaru@gmail.com, Phone: 0744296197
}<smiles>CC1(C)CCC2(C(=O)O)CC[C@]3(C)C(=CCC4[C@@]5(C)CCC(O)[C@](C)(CO)C5CC[C@]43C)C2C1</smiles>

Fig. 1. Hederagenin structure. Chemical formula $\mathrm{C}_{30} \mathrm{H}_{48} \mathrm{O}_{4^{\prime}}$ Molar mass $=472.1 \mathrm{~g} / \mathrm{mol}$

In the presentstudy, we aimed to isolate and characterize hederagenin from an extract of $H$. helix $\mathrm{L}$. leaves and to evaluate its biological activity. Isolated hederagenin ( $\mathrm{IHe})$ was analyzed by HPLC-MS/MS in negative ionization and compared to standard hederagenin. In vitro biocompatibility test was assessed in a culture of NCTC L929 mouse fibroblastcells, according to SR EN ISO 109935 , using dioscin as positive control. The antitumor activity was tested in a culture of human cervix carcinoma Hep2cells using MTT assay.

\section{Experimental part}

Plant material

Fresh leaves of $H$. helix L. obtained from Hofigal S.A. were dried at $40{ }^{\circ} \mathrm{C}$, for $48 \mathrm{~h}$ and stored in paper bags, at ambient temperature. The plant was authenticated and a voucher specimen (No. 407754) was deposited at the Botanical Garden of Bucharest, Romania.

\section{Isolation of hederagenin}

The ground dried leaves of $H$. helix L. (approx. $200 \mathrm{~g}$ ) were extracted by repeated maceration in $95 \%$ ( $v / v$ ) ethanol, at room temperature, with intermittent shaking, for 12 days (fig. 2). The ethanolic extract was concentrated under reduced pressure to a solid residue. The dried extract was 
subjected to acid hydrolysis by refluxing in ethanol: $\mathrm{H}_{2} \mathrm{SO}_{4}$ conc. 95:5 (v/v), for $3 \mathrm{~h}$. The hydrolysate was neutralized, refluxed in $5 \% \mathrm{KOH} /$ ethanol $(\mathrm{V} / \mathrm{v})$, for $30 \mathrm{~min}$ and filtrated using 3.5\% activated charcoal and $0.5 \%$ Celite. After addition of hot water, the extract was concentrated under reduced pressure to obtain a residue. The saponins from the residue were precipitated with acetonitrile and the resulting brown precipitate of IHe was dried and weighted $(1.78 \mathrm{~g})$.

\section{LC-MS/MS analyses}

LC-MS/MS analyses were performed on a triple quadrupole mass spectrometer model API3200 (Sciex) coupled with an Infiniti 1260 binary pump (Agilent) and autosampler. Analyst software version 1.5.2 was used for data acquisition and processing. Samples were separated on a Phenomenex Luna pentafluorophenyl (PFP2) column $(100 \times 2 \mathrm{~mm}, 3 \mu \mathrm{m}, 100 \AA)$ using a mobile phase composed of $A$ ) water with $0.1 \%$ formic acid and $B$ ) acetonitrile with $0.1 \%$ formic acid, at a flow rate of $0.275 \mathrm{~mL} / \mathrm{min}$. The injection volume was $15 \mu \mathrm{L}$. Standard hederagenin (Sigma-Aldrich) and IHe were dissolved in methanol, at a concentration of $1 \mathrm{mg} / \mathrm{mL}$ and, then, they were diluted to $5 \mu \mathrm{g} / \mathrm{mL}$ in methanol/water $(1: 1, \mathrm{v} / \mathrm{v})$ prior to injection in the LC-MS/MS system. The mass spectrometer ESI interface was operated in negative ions mode. Acquisitions were carried out in Q1 full scan over a mass/charge range from 250 to $1500 \mathrm{Da}$.

\section{Cell culture and treatment}

NCTC clone L929 cell culture of mouse fibroblasts and Hep-2 cell culture of human cervix carcinoma (ECACC, Sigma-Aldrich) were cultivated in Minimum Essential Medium (MEM), supplemented with $10 \%$ fetal bovine serum (FBS) (Biochrom), $2 \mathrm{mM} \mathrm{L-glutamine} \mathrm{and} \mathrm{a} \mathrm{mixture}$ of $100 \mathrm{U} / \mathrm{mL}$ penicillin, $100 \mu \mathrm{g} / \mathrm{mL}$ streptomycin and 500 $\mu \mathrm{g} / \mathrm{mL}$ neomycin (Sigma-Aldrich). For the experiments, NCTC fibroblast cells and Hep-2 tumor cells were seeded at a density of $4 \times 10^{4}$ cells $/ \mathrm{mL}$ and $6 \times 10^{4}$ cells $/ \mathrm{mL}$, respectively, in 96-wells culture plates. The cultures were incubated in $\mathrm{ABS} 1500$ biology security cabinet (Bioquell), provided with $5 \% \mathrm{CO}_{2}$ humid atmosphere, at $37^{\circ} \mathrm{C}$, for 24 $h$, to allow cell adhesion. Standard hederagenin, IHe and dioscin were solubilized in a small amount of dimethyl sulfoxide (DMSO) and diluted in the culture medium to obtain stock solutions, which were sterile filtered through $0.22 \mu \mathrm{m}$ membrane (Millipore). Fresh culture medium supplemented with $10 \%$ FBS, containing sample concentrations of $2,5,10,25,50,100,200,300$ and $400 \mu \mathrm{g} /$ $\mathrm{mL}$ was added over adhered cells. In the case of Hep-2 tumor cells, the samples were also diluted and analyzed in FBS-free culture medium [14]. The plates were incubated under standard conditions $\left(37^{\circ} \mathrm{C}, 5 \% \mathrm{CO}_{2}\right)$, for $24 \mathrm{~h}$ and 48 $h$. The in vitro cytotoxicity test was performed according to SR EN ISO 10993-5, using untreated cells as negative control and dioscin as positive control. The experiments were done in triplicate and the results were expressed as mean \pm standard deviation (SD).

\section{Cell viability assay (MTT assay)}

Cell viability was determined by MTT colorimetric method $[17,18]$ based on dimethylthiazol-2-yl diphenyl tetrazolium bromide (MTT) reduction under the action of mitochondrial dehydrogenase enzymes from metabolic active cells and formation of insoluble purple formazan crystals. Thus, the amount of generated formazan is directly proportional to the number of viable cells. For the experiment, the conditioned culture medium harvested at
$24 \mathrm{~h}$ and $48 \mathrm{~h}$ of incubation was replaced with $50 \mu \mathrm{g} / \mathrm{mL}$ MTT solution and the plates were incubated for $3 \mathrm{~h}$. After incubation, isopropanol was added to solubilize formazan crystals and the plates were placed on an orbital shaker, for 15 min. Optical density (OD) of the colored solution was measured at a wavelength of $570 \mathrm{~nm}$, using Mithras LB 940 microplate reader (Berthold Technologies). The results were calculated using the following formula:

$$
\% \text { cell viability }=(O D \text { sampe } / \text { OD control) } \times 100 \%
$$

\section{Results and discussions}

\section{Isolation and purification of IHe}

In our study, hederagenin, a saponin derivative of oleanolic acid, was isolated from an ethanolic extract of $H$. helix L. dried leaves. Acid hydrolysis of the extract was performed to remove the carbohydrate component and its purification was achieved by filtration and acetonitrile treatment. The brown precipitate of IHe was obtained with a yield of $0.89 \%$ (fig. 2 ).

In a previous study, Liu et al. (2014) have isolated hederagenin from ivy leaves using a similar method of extraction in $90 \%$ (v/v) ethanol and acid hydrolysis in $\mathrm{HCl}$, at $80^{\circ} \mathrm{C}$ [19]. Hederagenin was also isolated from the dried

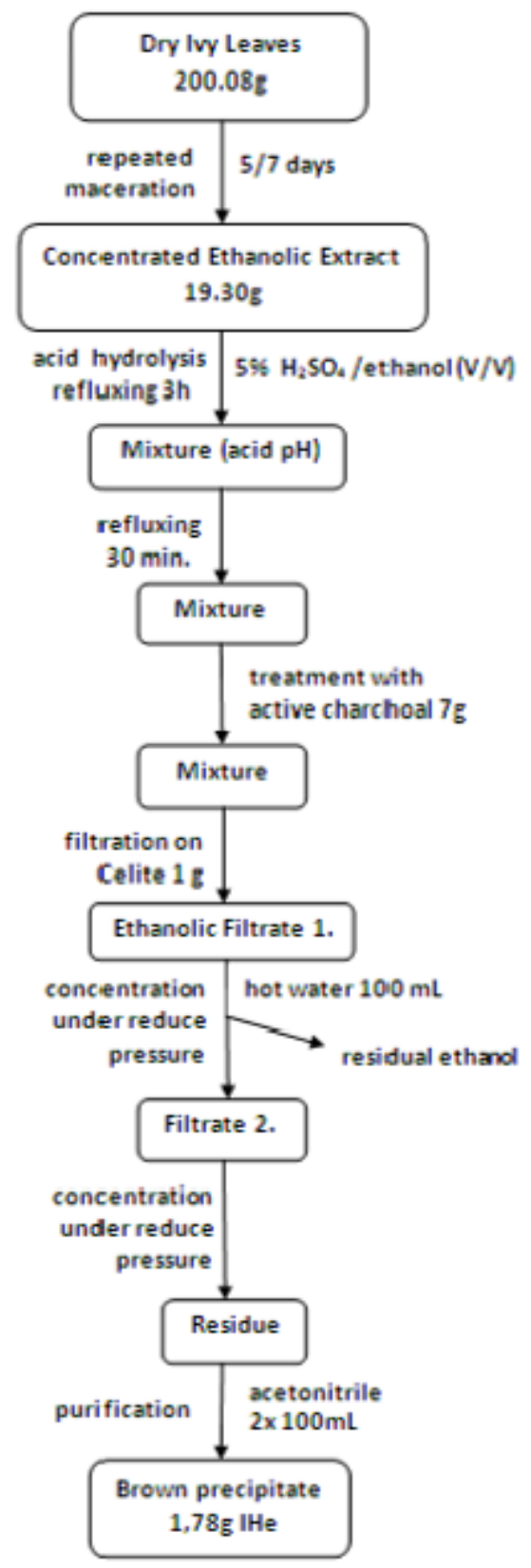

Fig. 2. Isolation of hederagenin from Hedera helix L. leaves 
pericarp of S. saponaria fruits by extraction in $70 \%(\mathrm{v} / \mathrm{v})$ methanol and the yield was $0.9 \%$ [4]. Three hederagenintype triterpene saponins were isolated from the aerial parts of Cephalaria aristata (Dipsacaceae) by alkaline hydrolysis of the bisdesmosidic compounds [20].

\section{LC-MS/MS characterization}

IHe sample was analyzed by HPLC-MS/MS to identify the presence of hederagenin by comparison to standard hederagenin and on basis of molecular mass. LC-MS/MS chromatograms are presented in figures $3 a$ and $3 b$. Deprotonated molecular ions were observed in the analyzed sample, in negative ionization. Hederagenin was identified in the sample, considering the molecular ions and their corresponding retention times. Estimation of hederagenin content was achieved from LC-MS/MS signal intensity of standard saponin that indicated a concentration of $10 \mu \mathrm{g} / \mathrm{mL}$ hederagenin in IHe sample.

\section{In vitro biocompatibility testing}

The biocompatibility of IHe was tested in a culture of NCTC fibroblastcells, using a wide range of concentrations between $2-400 \mu \mathrm{g} / \mathrm{mL}$, at $24 \mathrm{~h}$ and $48 \mathrm{~h}$ of incubation. MTT assay results obtained for IHe sample are presented in figure 4 , in comparison to standard hederagenin and dioscin, used as positive control. For IHe concentrations between 2-200 $\mu \mathrm{g} / \mathrm{mL}$, the values of cell viability were higher than $80 \%$ (fig. 4), indicating that the sample was biocompatible. In the range of concentrations $200-400 \mu \mathrm{g} / \mathrm{mL}$, the cell viability varied between $60-80 \%$, after $24 \mathrm{~h}$ of cultivation, showing that IHe sample was moderate cytotoxic for NCTC fibroblasts. The cytotoxic effect of IHe increased after $48 \mathrm{~h}$ of cultivation in the fibroblast cell culture, in a concentration dependent manner.

Standard hederagenin was biocompatible in the range of concentrations $2-50 \mu \mathrm{g} / \mathrm{mL}$ and moderate cytotoxic at higher concentrations ranging between $100-300 \mu \mathrm{g} / \mathrm{mL}$. At $400 \mu \mathrm{g} / \mathrm{mL}$, the cell viability decreased by more than $50 \%$, after $48 \mathrm{~h}$ of cultivation. The observed difference between IHe sample and standard hederagenin regarding their in vitro cytotoxicity in a fibroblastcell culture could be explained by the smaller concentration of hederagenin in IHe sample.

Dioscin, a natural steroid saponin known for its antitumor effect [21] was biocompatible in NCTC cell culture only at concentrations of $2-5 \mu \mathrm{g} / \mathrm{mL}$ ( $>70 \%$ cell viability). Athigher concentrations, dioscin had a cytotoxic effect that increased from moderate ( $>50 \%$ cell viability) to severe in the culture of fibroblast cells.

\section{Antitumor activity}

In our study, the antitumor activity of IHe isolated from ivy leaves was investigated in the concentration range of 2-400 $\mu \mathrm{g} / \mathrm{mL}$ in a culture of Hep-2 human cervix carcinoma, cultivated in MEM with and without FBS, respectively. The results of MTT assay obtained for IHe sample are presented in figure 5 , in comparison to standard hederagenin and dioscin.

IHe sample cultivated in Hep-2 cell culture, in the presence of FBS presented values of cell viability higher than $80 \%$, at $24 \mathrm{~h}$ and $48 \mathrm{~h}$, indicating the absence of antitumor activity. A slight cytotoxicity was manifested only at IHe concentrations higher than $300 \mu \mathrm{g} / \mathrm{mL}$, after $48 \mathrm{~h}$ of cultivation (fig. 5a). The tumoral cells treated with IHe concentrations higher than $50 \mu \mathrm{g} / \mathrm{mL}$ and cultivated in the absence of FBS presented a decrease in cell viability below the threshold of $80 \%$ (fig. 5a). These data indicated that IHe had increasing antitumor effect, dependent on concentration, with the highest activity registered at a concentration of $400 \mu \mathrm{g} / \mathrm{mL}$, at both $24 \mathrm{~h}(60.41 \%)$ and $48 \mathrm{~h}$ $(42.1 \%)$ of cultivation.

Standard hederagenin exerted a cytotoxic effect at higher concentrations than $25 \mu \mathrm{g} / \mathrm{mL}$, in both experimental models of cultivation, MEM with or without FBS (fig. $5 b$ ). Hep-2 cells cultivated in medium with FBS and treated with $50 \mu \mathrm{g} / \mathrm{mL}$ hederagenin, presented a cell viability of $69.19 \%$ at $48 \mathrm{~h}$ of incubation, while treatment with $400 \mu \mathrm{g} /$ $\mathrm{mL}$ hederagenin induced a decrease of cell viability to $55.28 \%$. Similar, tumoral cells cultivated in medium without FBS and treated with $50 \mu \mathrm{g} / \mathrm{mL}$ hederagenin had $51.62 \%$ cell viability, which decreased to $41.53 \%$ for treatment with $400 \mu \mathrm{g} / \mathrm{mL}$ hederagenin.
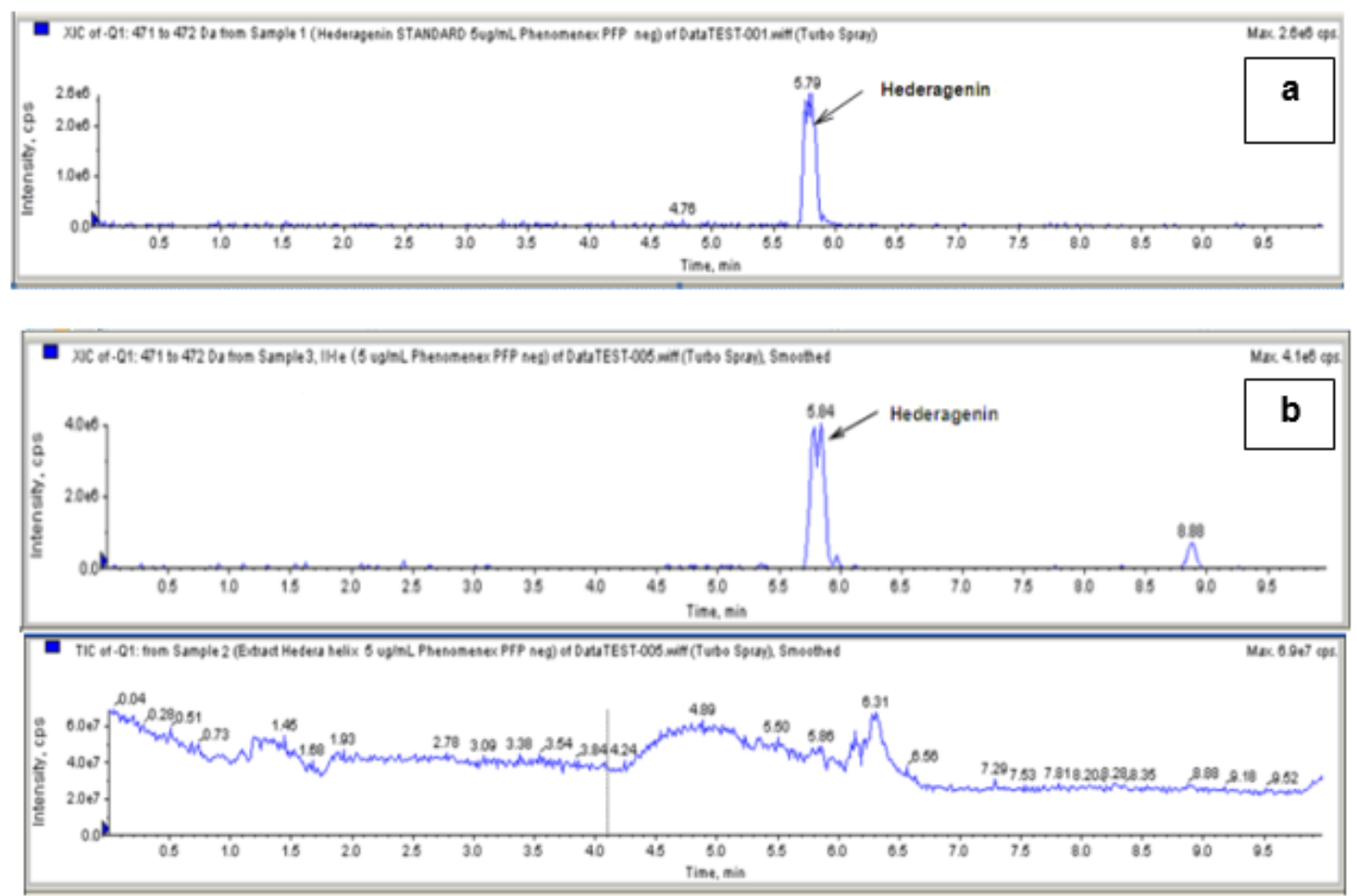

Fig. 3. LC-MS/MS chromatograms of standard hederagenin (a) and isolated hederagenin (IHe) (b) 
MTT results of IHe sample, He standard and Dioscin on NCTC cells at $24 \mathrm{~h}$

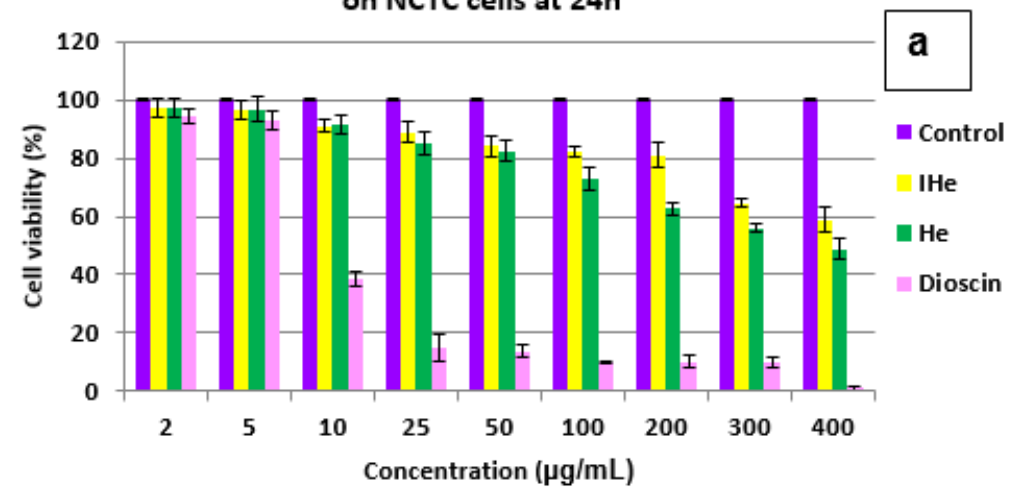

MTT results of IHe sample, He standard and Dioscin on NCTC cells at $48 \mathrm{~h}$

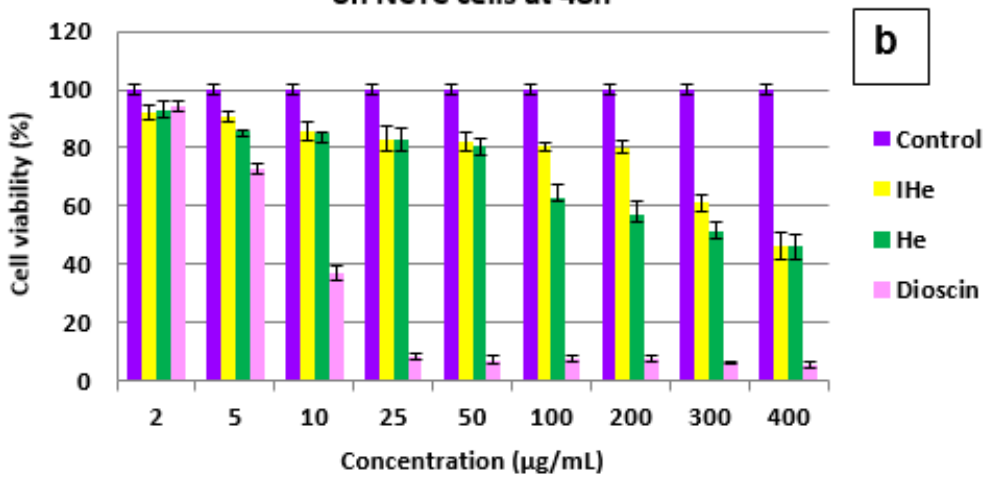

Fig. 4. Cytotoxicity of IHe, standard hederagenin (He) and dioscin in a culture of NCTC fibroblast cells, after $24 \mathrm{~h} \mathrm{(a)}$ and $48 \mathrm{~h}$ (b) of cultivation, determined by MTT assay. Untreated cells were used as control and considered $100 \%$ viable. The experiments were performed in triplicate and the results were expressed as mean \pm SD
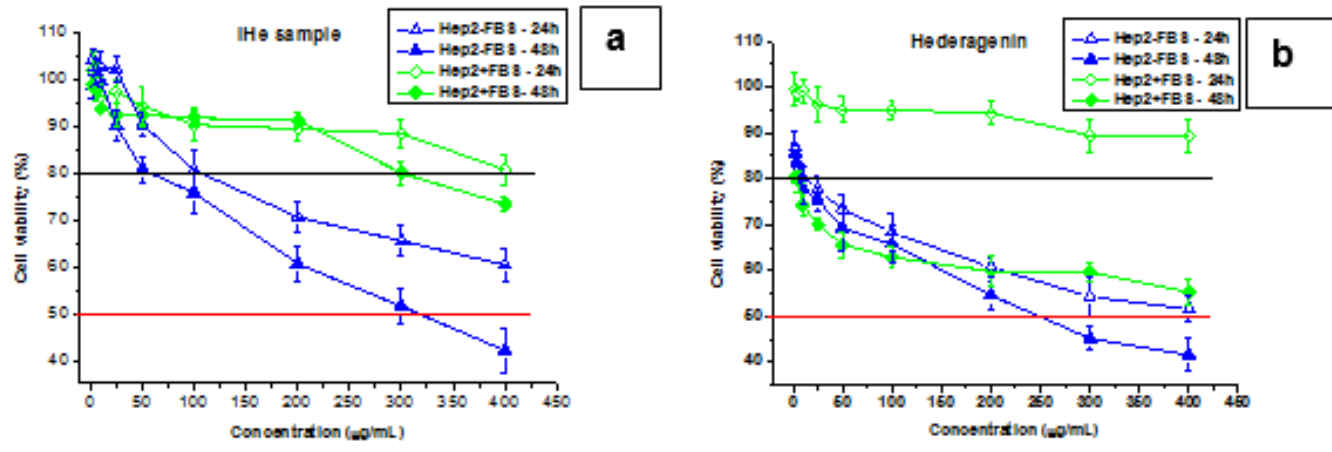

Fig. 5. Antitumor activity of IHe sample (a), standard hederagenin (b) and dioscin $(c, d)$ determined in a culture of Hep-2 human
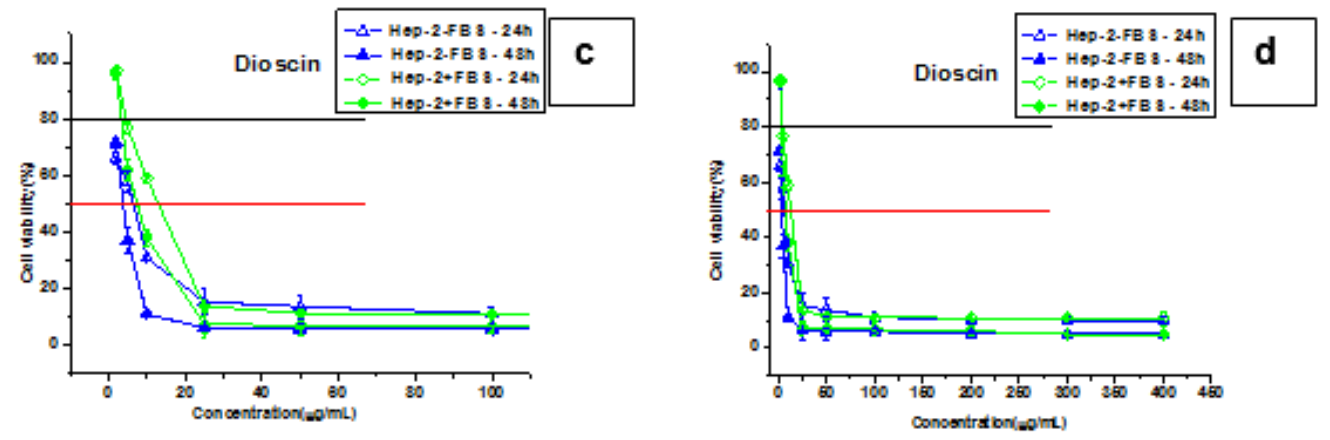

carcinoma cells by MTT assay, at $24 \mathrm{~h}$ and $48 \mathrm{~h}$ of cultivation

Dioscin was tested, as positive control, in Hep-2 tumoral cells in the same range of concentrations. Only at $2 \mu \mathrm{g} / \mathrm{mL}$ dioscin, the cells cultivated in the presence of FBS showed viability values higher than $70 \%$ (fig. $5 \mathrm{c}$ ). At concentrations between $10-400 \mu \mathrm{g} / \mathrm{mL}$, dioscin induced a cytotoxic effect in Hep-2 cultured cells, presenting pronounced antitumor activity (fig. $5 \mathrm{~d}$ ). The profile of cell viability decrease was observed in both experimental models of tumoral cells cultivated with or without FBS.

Previous studies revealed that a total extract of ivyleaves encapsulated in nanostructured lipid carriers presented antitumor activity in a culture of B16 melanoma cell line, at a concentration of $200 \mu \mathrm{g} / \mathrm{mL}$ [22]. The cell viability decreased to values of $64-71 \%$ at $72 \mathrm{~h}$ of cultivation, probably due to the variety of phytochemical compounds present in the total extract of ivy leaves. The antitumor activity of saponins isolated from the aerial parts of Cephalaria species (from Turkey) was investigated using in vitro bioassays and showed that hederagenin was the most active compound against lung cancer cells [23].

Antitumor compounds are known to inhibit, delay or reverse cancer progression mainly through cytotoxic or apoptosis effect [24]. In our study, the antitumor activity of 
tested samples was also calculated and expressed as the minimum inhibition concentration that causes the death of $50 \%$ cells (IC50) (table 1 ).

The results indicated similar values for IHe sample ( 320 $\mu \mathrm{g} / \mathrm{mL})$ and standard hederagenin $(250 \mu \mathrm{g} / \mathrm{mL})$ in cells cultivated without FBS. The experimental model of cells

Table 1

VALUES OF IC50 DETERMINED FOR IHe SAMPLE, STANDARD HEDERAGENIN AND DIOSCIN

\begin{tabular}{|c|c|c|}
\hline \multirow{2}{*}{ Sample } & \multicolumn{2}{|c|}{ IC50 $(\mu \mathrm{g} / \mathrm{mL})$} \\
\cline { 2 - 3 } & Hep-2-FBS & Hep-2+FBS \\
\hline IHe sample & 320 & $>400$ \\
\hline $\begin{array}{c}\text { Standard } \\
\text { hederagenin }\end{array}$ & 250 & $>400$ \\
\hline Dioscin & 3 & 6 \\
\hline
\end{tabular}

cultivated in the presence of FBS revealed that IC50 values were higher than $400 \mu \mathrm{g} / \mathrm{mL}$ for IHe sample and standard hederagenin. Dioscin, known as cell apoptosis inducer, presented IC50 values as low as $3 \mu \mathrm{g} / \mathrm{mL}$ in culture medium without FBS and $6 \mu \mathrm{g} / \mathrm{mL}$ in culture medium with FBS. The cell culture data indicated that IHe was similar to standard hederagenin in regard of its antitumor activity. It was reported that the antitumor activity of triterpenoid saponins could be linked to their ability to block nuclear factor-kB activation, induce apoptosis, inhibit signal transduction and activate transcription or angiogenesis [ 1 , 25].

\section{Conclusions}

An ethanolic extract of $H$. helix leaves was used to isolate hederagenin by acid hydrolysis. IHe was purified by filtration and acetonitrile treatment. HPLC-MS/MS analysis of $\mathrm{IHe}$, in negative ionisation, indicated the presence of hederagenin. Cytotoxicity tests in normal fibroblast NCTC cells showed that IHe has high biocompatibility at concentrations between $2-200 \mu \mathrm{g} / \mathrm{mL}$. MTT assay results revealed the inhibition of tumoral Hep-2 cells viability in an IHe concentration-dependent manner. The obtained hederagenin presented antitumor activity in human cervix carcinoma Hep-2 cells cultivated in medium without FBS. Similarities in IC50 values were observed between IHe and commercial hederagenin. All these results demonstrated that hederagenin isolated from $H$. helix leaves might be a potent therapeutic candidate with antitumor activity.
Acknowledgment. This work was supported by a grant of the Romanian Ministry of Research and Innovation, CCCDI-UEFISCDI, Project No. PN-III-P1-1.2-PCCDI-2017-0569.

\section{References}

1. ADESEGUN, S.A., COKER H.A.B., HAMANN, M.T., J. Nat. Prod., 77, 2014, p. 155

2. EVANS, W.C., Trease and Evans Pharmacognosy, $16^{\text {th }}$ ed., Elsevier Science Ltd., UK, 2009

3. BOJ OR, O., Ghidul Plantelor Medicinale si Aromatice de la A la Z, Ed. Fiat Lux, Bucuresti, 2003

4. RODRIGUEZ-HERNANDEZ, D., DEMUNER, A.J ., BARBOSA, L., CSUK, R., HELLER, L., Eur. J. Med. Chem., 105, 2015, p. 57

5. BEDIR, E., KIRMIZIPEKMEZ, H., STICHER, O., CALIS, I., Phytochemistry, 53, no. 8, 2000, p. 905

6. ELIAS, R., LANZA, A.M.D., VIDAL-OLLIVIER, E., BALANSARD, G., FAURE, R., BABADJ AMIAN, A., J. Nat. Prod., 54, no. 1, 1991, p. 98 7. SAHA, S., WALIA, S., KUMAR, J., BALRAJ, P., Pest. Manag. Sci., 66, 2010, p. 825

8. RIBEIRO, A., ZANI, C.L., ALVES, T.M.A., MENDES, N.M., HAMBURGER, M., HOSTETTMANN, K., Int. J. Pharmacogn., 33, no. 3, 1995, p. 177 9. GAUTHIER, C., LEGAULT, J., GIRARD-LALANCETTE, K., MSHVILDADZE, V., PICHETTE, A., Bioorg. Med. Chem., 17, no. 5, 2009, p. 2002

10. TAKAGI, K., PARK, K., KATO, H., Chem. Pharm. Bull., 28, no. 4, 1980, p. 1183

11. FRANCIS, G., KEREM, Z., MAKKAR, H.P.S., BECKER, K., Br. J. Nutr., 88, no. 6, 2002, p. 587

12. ALBIERO, A.L.M., SERTIE, J .A.A., BACCHI, E.M., J. Ethnopharmacol., 82, no. 1, 2002, p. 41

13. GULCIN, I., MSHVILDAZE, V., GEPDIREMEN, A., ELIAS, A., Planta Med., 70, no. 6, 2004, p. 561

14. TIMON, P., JULIEN, J., GASQUET, M., BALANSARD, G., BERNARD, P., Ann. Pharm. Fr., 38, no. 6, 1980, p. 545

15. DANLOY, S., QUETIN-LECLERCQ, J ., COUCKE, P., DE PAUW-GILLET, M.C., ELIAS, R., BALANSARD, G., ANGENOT, L., BASSLEER, R., Planta Med., 60, no. 1, 1994, p. 45

16. WANG, C.Z., LI, X.L., WANG, Q.F., MEHENDALE, S.R., FISHBEIN, A.B., HAN, A.H., SUN, S., YUAN, C.S., Oncol. Rep., 21, no. 3, 2009, p. 577

17. MOSMANN, T., J. Immunol. Methods, 65, no. 1-2, 1983, p. 55

18. MOLDOVAN, L., CRACIUNESCU, O., BALAN, M., GASPAR, A., GHERGHINA, E., Rev. Chim.(Bucharest), 59, no. 9, 2008, p. 1022

19. LIU, B.X., ZHOU, J.Y., LI, Y., ZOU, X., WU, J., GU, J.F., YUAN, J.R., ZHAO, B.J ., FENG, L., JIA, X.B., WANG, R.P., BMC Complement. Altern. Med., 14, 2014, p. 412

20. ARISTATOSIDES, A-C., Phytochem. Lett., 8, 2014, p. 149

21. MAN, S.,GAO, W.,ZHANG, Y.,HUANG, L., LIU, C., Fitoterapia, 81, no. 7, 2010, p. 703

22. LACATUSU, I., BADEA, N., BADEA, G., BRASOVEANU, L., STAN, R., OTT, C., OPREA, A., MEGHEA, A., RSC Adv., 81, no. 6, 2016, p. 77243 23. SARIKAHYA, N.B., NALBANTSY, A., TOP, H., GOKTURK, R.S., SUMBUL, H., KIRMIZIGUL, S., Phytomedicine, 38, no. 1, 2018, p. 135 24. KANSAL, S., NEGI, A.K., AGNIHOTRI, N., Curr. Colorectal Cancer Rep., 8, no.4, 2012, p. 307

25. PETRONELLI, A., PANNITTERI, G., TESTA, U., Anticancer Drugs, 20 , no. 10,2009 , p. 880

$\overline{\text { Manuscript received: } 5.06 .2018}$ 